\title{
Modelling \& Analysis of a Fuel Cell Hybrid Electric Vehicle using Real-World \& Standard Driving Conditions
}

\author{
Raees B. K. Parambu, Mike Dempsey, Alessandro Picarelli \\ Claytex Services Ltd, Edmund House, Rugby Road, Leamington Spa, CV32 6EL, United Kingdom \\ E-mails: \{raees.parambu, mike.dempsey, alessandro.picarelli\}@claytex.com
}

\begin{abstract}
This paper presents an acausal model-based systemlevel simulation of a fuel cell plug-in hybrid electric vehicle (FCPHEV) (also known as the H2EV) in Dymola. The modelling part includes the development of a full vehicle and its subcomponents. The simulation (analysis) part involves investigation of the vehicle performance, fuel economy $\left(\mathrm{Wh} / \mathrm{km}\right.$ or $\left.\mathrm{gH}_{2} / \mathrm{km}\right)$ and carbon footprint $\left(\mathrm{C}_{\mathrm{f}}\right)$ using both standard \& real-world (UK) and homologation (Japan) driving conditions. The effect of the addition of auxiliary load on vehicle range is also explored based on these two countries in conjunction with corresponding drive cycles. Comparing to a commercial FCEV, the well-to-wheel (WTW) analysis results show that by adopting the proposed H2EV during Japan Olympics 2020, $\mathrm{C}_{\mathrm{f}}$ can be reduced and fuel economy improved with an assumption that Japan produces hydrogen fuel from renewable energy resources only.
\end{abstract}

Keywords: Acausal, Model, Fuel cell, Battery, Hybrid, Vehicle, Fuel Economy, Carbon Footprint, Real-world, Standard, Drive, Cycle, Dymola.

\section{Introduction}

In the past five years, an increased penetration of electric vehicles (EVs) into the road transportation system has been recorded worldwide [1]. This includes the battery (BEV), plug-in hybrid (PHEV) and fuel cell (FCEV) type electric vehicles. In the year 2016, China and US were the two major contributors of EVs, followed by Japan, and the UK comes in the $6^{\text {th }}$ position [1]. Although the FCEV or its variant (fuel cell plug-in hybrid electric vehicle (FCPHEV)) have a potential to decarbonise our road transport completely, this can only be achieved by a joint effort of producing hydrogen fuel solely from renewable energy resources [2] and with smart refuelling stations.

Despite various challenges, the development of fuel cell (FC) based vehicles has been accelerated and mainly noticed in the past major events (e.g., Olympics and World Expo) worldwide. In 2012, during the London Olympics, several FC powered Taxis were introduced [3]. In the past ten years, China has been continuously developing FC powered vehicles (such as cars, buses, etc.), and demonstrated their technical capabilities during their previous major events [4].

According to [5], both the national and local governments of Japan have been spending about \$360 million for developing up to $6000 \mathrm{FCHVs}$ and 35 stations by 2020 . The main focus of this project is to achieve a target of running the Tokyo Olympics 2020 mostly on hydrogen-powered vehicles. This has generated a significant industrial opportunity and challenges for many companies (like Honda and Toyota). For the successful implementation of this kind of project within the time-frame, it is worth looking at existing FC based vehicles across the world and considering model-based systems engineering feasibility studies using these vehicles under different operating conditions. Such methods can save significant amount of time and engineering resources.

Microcab Ltd is a UK based spin-off company of Coventry University and has a connection with the University of Birmingham and several hydrogen-based research institutes both in the UK and globally [6]. They have been developing lightweight FCPHEVs for several years, and some of their successful projects are given in $[7,8]$. The latest version of their vehicle is known as H2EV (a plug-in series hybrid FC-Battery powertrain) primarily designed for urban use. This vehicle has proved to work well in the West Midlands area of the UK and potentially in Northern/Central Europe [9]. However, the majority of their work is based on the development of physical prototypes and testing of H2EVs on both a chassis dynamometer (rolling road) and real-world driving conditions [9]. Furthermore, there is a lack of publicly available resources in relation to an acausal system-level model of H2EVs.

Dymola (Dynamic Modeling Laboratory) is a systems-engineering tool for modelling multiengineering multi-physical complex systems based on Modelica (an equation-based object-oriented) modelling language. There are few research papers in the literature focused on modelling of FC powertrain especially using Modelica language [10-12]. However, neither of them based on the modelling of an existing H2EV nor validated against realistic drive test data especially based on a normal everyday driving scenario in the West Midlands area in the UK. Moreover, there is no feasibility study available on adoption of H2EV for an upcoming large event, the Japan Olympics 2020.

Therefore, this research paper aims to develop an acausal system-level model of a H2EV in Dymola and analyse the performance, fuel economy and carbon footprint $\left(\mathrm{C}_{\mathrm{f}}\right)$ of this vehicle under different driving conditions. For this purpose, a full H2EV model is developed by mostly adapting component models from a commercial library. This full vehicle model is then 
validated against publicly available (including realworld, also called Coventry Drive Cycle (CDC) experimental test data based in the UK. For predicting the performance of H2EV in Japanese road conditions, the developed H2EV model is then simulated with the standard Japanese JC08 drive cycle. Following on, two case studies are conducted to explore the impact of parasitic loads on the performance of the $\mathrm{H} 2 \mathrm{EV}$ in the above chosen two countries. Finally, a well-to-wheel (WTW) analyses are performed for comparing the fuel economy and carbon footprint $\left(\mathrm{C}_{\mathrm{f}}\right)$ of $\mathrm{H} 2 \mathrm{EV}$ relative to a commercial FCHEV in Japan.

\section{Dymola Model Overview}

A system-level H2EV model is created in Dymola with the help of a commercial Modelica library, VeSyMA (Vehicle Systems Modelling and Analysis) from Claytex Services Limited [13].

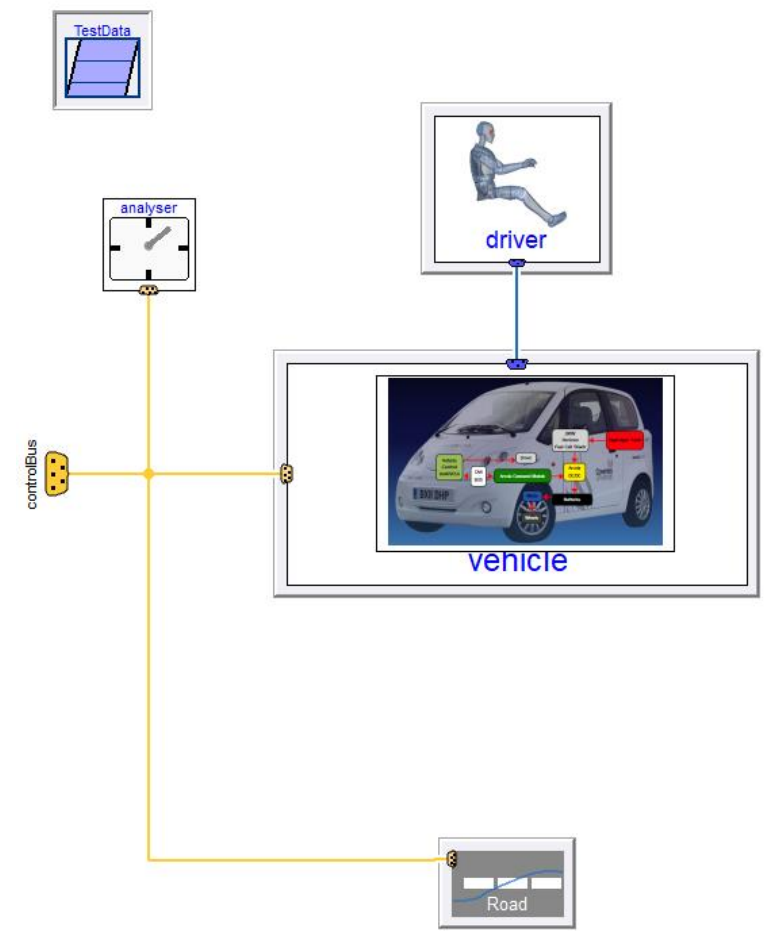

Figure 1. The full system-level model of a H2EV [Courtesy: Microcab H2EV image is used].

The VeSyMA library provides a top-level adaptable vehicle template layout in Figure 1. This paper has modified and used this template as the framework to integrate all the systems. In Figure 1, the top-level model consists of a driver, vehicle, road, analyser (to collect or calculate the most important vehicle variables such as power consumption, efficiency, emission, $\left(\mathrm{C}_{\mathrm{f}}\right)$ etc.) and a Modelica record (TestData) with parameters of the selected H2EV. Many component models are taken directly from VeSyMA, and others such as fuel cell, hydrogen tank, auxiliary load unit (ALU) and analyser are additionally created. For enhancing the simulation speed, the component models in VeSyMA (like battery, motor and controllers) are modified.

\subsection{Vehicle Propulsion System Architecture}

The architecture of the vehicle model in Figure 1 is shown in Figure 2. This vehicle model is divided into the following subsystems: (1) fuel cell, (2) tank, (3) battery, (4) electric drive ((ED) motor \& power converter), (5) ALU, (6) driver environment, (7) chassis and (8) vehicle parameters' record. The controller of each subsystem is built within its corresponding model.

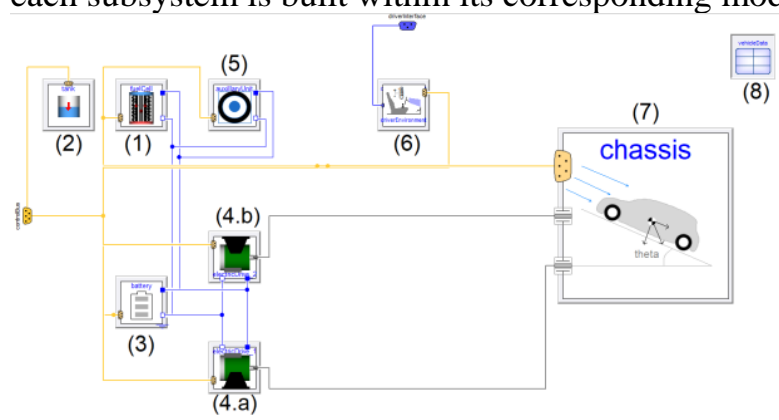

Figure 2. The architecture of H2EV with its subsystems models.

The structure of the chassis model in Figure 2 shown in Figure 3, which is further partitioned into driveline (contains gearboxes), resistance (contains aerodynamic, rolling and inclination resistances, wheels and mass) and brake models.

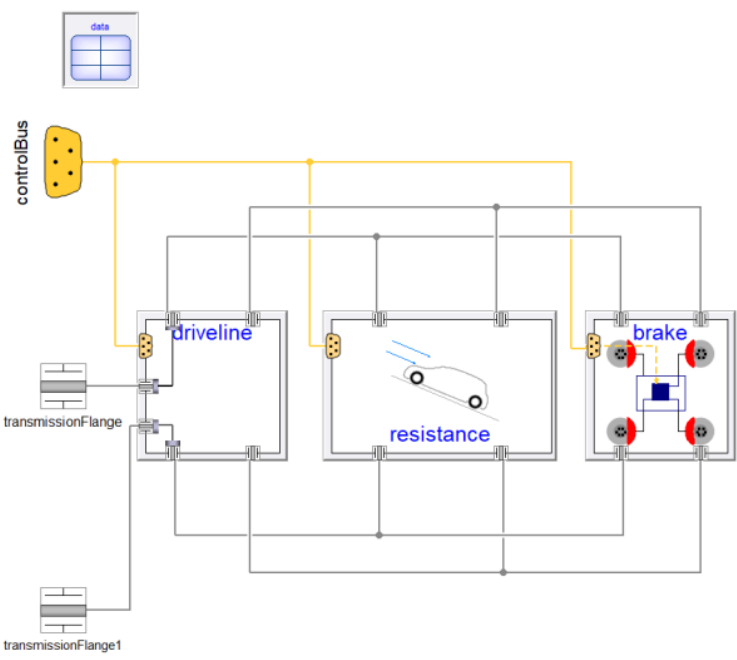

Figure 3. The structure of the chassis model.

The overall operation of the system-level model of $\mathrm{H} 2 \mathrm{EV}$ is summarised as follows: when driver presses the accelerator pedal, a positive torque is requested to vehicle and the powertrain delivers power. On the other hand, when the driver is pressing on the brake pedal, a negative torque is requested. As in Figure 1, the driver demands are fed to the vehicle model via a bus system.

\subsection{Vehicle Specification and Model Parameters}

Vehicle parameter values used in this paper are those for an existing H2EV but are taken from various resources $[9,13-15]$ and only public domain values or educated estimates are used. Moreover, H2EV is a multi-purpose 
vehicle, and can be used in four different situations. These details are also included in the bottom of Table 1 .

Table 1. System-level specifications and model parameters used in this paper [9, 13-15].

\begin{tabular}{|c|c|}
\hline Description & Parameter (value) \\
\hline $\begin{array}{l}\text { Vehicle general } \\
\text { description }\end{array}$ & $\begin{array}{l}\text { Four seats lightweight niche } \\
\text { vehicle }\end{array}$ \\
\hline $\begin{array}{l}\text { Kerb (gross } \\
\text { vehicle) weight }\end{array}$ & $750 \mathrm{~kg}$ \\
\hline Top speed & under $90 \mathrm{~km} / \mathrm{h}(55 \mathrm{mph})$ \\
\hline $\begin{array}{l}\text { Propulsion } \\
\text { (powertrain) }\end{array}$ & $\begin{array}{l}\text { a plug-in series hybrid } \\
\text { FC-Battery (FCPHEV) }\end{array}$ \\
\hline Fuel cell & $\begin{array}{l}3 \mathrm{~kW} \text { (continuous) air-cooled } \\
\text { Horizon open cathode H-3000 }\end{array}$ \\
\hline Hydrogen tank & $\begin{array}{l}\text { Pressure }=350 \mathrm{bar} \\
\text { Capacity }=74 \text { litre (holding } \\
\text { capacity of } 1.8 \mathrm{~kg} \text { 's of hydrogen) }\end{array}$ \\
\hline Battery & $72 \mathrm{~V} 4.3 \mathrm{kWh} \mathrm{LiFePO}_{4}$ \\
\hline DC motors & $\begin{array}{l}12.5 \mathrm{~kW} \text { front wheel drive } \\
\text { (Lynch LEM-200/d127) }\end{array}$ \\
\hline $\begin{array}{l}\text { Power converter } \\
\text { type }\end{array}$ & DC/DC converter \\
\hline $\begin{array}{l}\text { Total no. of } \\
\text { motors }\end{array}$ & 2 \\
\hline $\begin{array}{l}\text { Combined peak } \\
\text { power of motors }\end{array}$ & $40 \mathrm{~kW}$ \\
\hline $\begin{array}{l}\text { Fuel cell weight } \\
\text { and its } \\
\text { associated } \\
\text { systems }\end{array}$ & Appro. $60 \mathrm{~kg}$ \\
\hline $\begin{array}{l}\text { Range (fully } \\
\text { charged battery } \\
\& \text { full tank) }\end{array}$ & up to $290 \mathrm{~km}$ (180 miles) \\
\hline Refuelling time & $3 \min$ \\
\hline Dimensions & $\begin{array}{l}\text { Length }=3.5 \mathrm{~m}, \text { Height }=1.7 \mathrm{~m} \text {, } \\
\text { Width }=1.6 \mathrm{~m}\end{array}$ \\
\hline Chassis & Lotus bounded aluminium \\
\hline $\begin{array}{l}\text { Transmission } \\
\text { type }\end{array}$ & Belt drive to front wheels \\
\hline \multicolumn{2}{|c|}{ Multi-purpose format } \\
\hline Car format & 4 seats \\
\hline Van format & 2 seats (200 kg payloads) \\
\hline Taxi format & Diver and $2 / 3$ passengers \\
\hline Taxi details & Flat floor for full accessibility \\
\hline
\end{tabular}

\subsection{Component Models}

\subsubsection{Driver}

For simulating a vehicle in Dymola, it is important to provide an input excitation (such as a drive cycle) using a driver model shown in Figure 1. A real driver typically commands propulsion through accelerator and brake pedals. The chosen model is a longitudinal driver model from VeSyMA. It reads the speed-time demands from the provided drive cycle and has a longitudinal closed loop feedback control.

\subsubsection{Fuel Cell Stack}

In this paper, the system under observation is the commercially available $3 \mathrm{~kW}, 72$ cells, Proton Exchange Membrane fuel cell (PEM FC) stack from Horizon Fuel Cells Technologies [15].

The main advantage of this type of FC is that it produces water as a residue, with high efficiency compared to Internal combustion engines (ICEs). It can operate at low temperatures and allows a fast start-up. Because of these reasons, as of today, it is one of the best options for automotive traction applications. A solid-polymer based electrolyte is very common in this type of FCs.

The overall operation of a PEM FC can be expressed as; Overall reaction:

$$
\begin{aligned}
\mathrm{H}_{2}(g)+\frac{1}{2} \mathrm{O}_{2}(g) & \\
& \rightarrow \mathrm{H} 2 \mathrm{O}(l)+\text { electric energy } \\
& + \text { wasteheat }
\end{aligned}
$$

At anode:

$$
H_{2}(g) \rightarrow 2 H^{+}(a q)+2 e^{-}
$$

At cathode:

$$
\frac{1}{2} \mathrm{O}_{2}(g)+2 \mathrm{H}^{+}(a q)+2 e^{-} \rightarrow \mathrm{H} 2 \mathrm{O}(l)
$$

In this paper, a dynamic FC cell model based on $[16,17]$ is implemented as shown in Figure 4. It includes five major parts; (1) $V_{\text {rev }}$, the reversible (Nernst) voltage, (2) $V_{a c t}$, an activation polarisation (to represent voltage drop associated with the activation of anode and cathode), (3) $V_{\text {conc }}$, the concentration polarisation (voltage drop resulting from the decrease in the concentration of oxygen and hydrogen), (4) an ohmic loss (to represent resistance of the proton transfer through the polymer membrane). Both activation and concentration polarisations are modelled within the polarisation model in Figure 4, and (5) a double layer capacitance is connected parallel to the polarisation model.

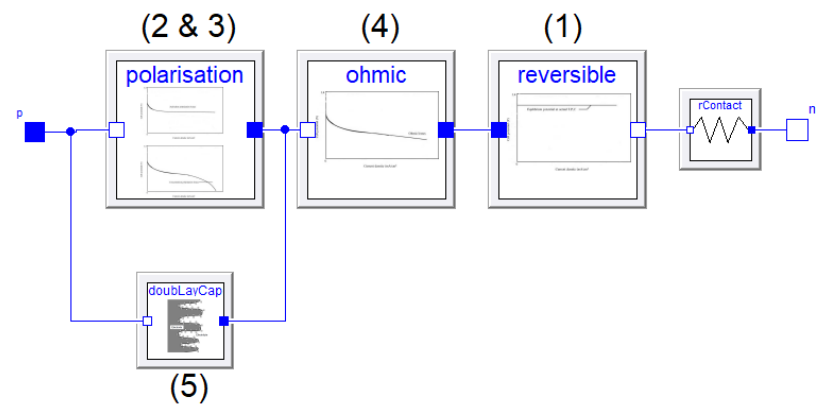

Figure 4. Structure of the FC cell model.

The FC cell voltage, $V_{F C_{c e l l}}$ and its each term can be defined as below [16];

$$
V_{F C_{\text {cell }}}=V_{\text {rev }}+V_{\text {act }}+V_{\text {ohm }}+V_{\text {conc }}
$$




$$
\begin{gathered}
V_{\text {rev }}=-E^{0}-\frac{R T}{2 F} \ln \left(\frac{P_{\mathrm{H}_{2} \mathrm{O}}}{P_{\mathrm{H}_{2}} \cdot P_{O_{2}}^{1 / 2}}\right) \\
V_{\text {act }}=-\frac{R T}{2 \alpha F} \ln \left(\frac{i_{F C_{\text {cell }}}+i_{\text {loss }}}{i_{0}}\right) \\
V_{\text {ohm }}=-\left(i_{F C_{\text {cell }}} \cdot A S R\right) \\
V_{\text {conc }}=-m \cdot i_{F C_{\text {cell }}}{ }^{k} \ln \left(1-\frac{i_{F C_{\text {cell }}}}{i_{L}}\right)
\end{gathered}
$$

where, $E^{0}=\frac{G_{f, l i q}}{2 F}$ is the electromotive force (EMF) of the cell at standard pressure, $G_{f, l i q}$ is the Gibbs function in liquid form, $R$ and $F$ are the molar and Faraday's constants, $T$ is the cell internal temperature, $P_{\mathrm{H}_{2}}, P_{\mathrm{O}_{2}}$, and $P_{\mathrm{H}_{2} \mathrm{O}}$ are the partial pressure of hydrogen, oxygen and water respectively, $\alpha$ is the charge transfer coefficient, $i_{F C_{\text {cell }}}$ is the cell current density, $i_{\text {loss }}$ and $i_{0}$ are internal current and exchange current densities, $A S R$ is the area specific resistance, $m$ and $k$ are the amplification and mass transport constants, and $i_{L}$ is the limiting current.

In this paper, the individual FC cell model described above is scaled using a specific number of cell in series $\left(N_{\text {cell }}\right)$ to represents a full FC stack model as shown in Figure 5.

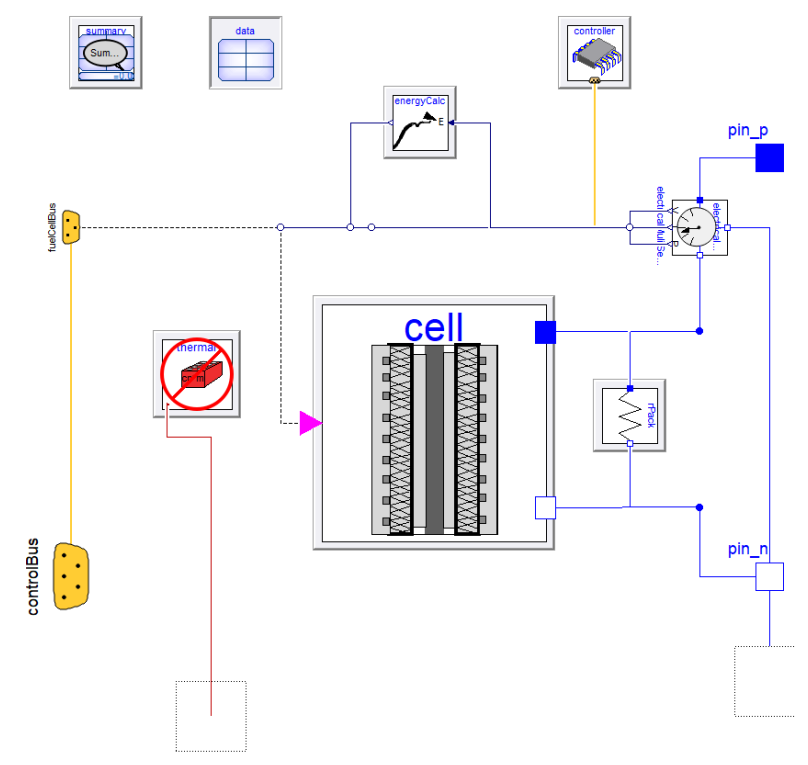

Figure 5. Structure of the FC stack model.

The FC stack current $\left(I_{F C}\right)$, power $\left(P_{F C}\right)$ and efficiency $\left(\eta_{F C}\right)$ are defined as below;

$$
\begin{gathered}
I_{F C}=i_{F C_{\text {cell }}} A_{\text {cell }} \\
P_{F C}=N_{\text {cell }} \times V_{F C_{\text {cell }}} \times I_{F C} \\
\eta_{F C}=\frac{V_{F C_{\text {cell }}}}{1.482}
\end{gathered}
$$

where $A_{\text {cell }}$, the cell active area. FC cell model parameters are taken mainly from [16] and rest of them are estimated to match with Table 1 system level values.

\subsubsection{Hydrogen Tank}

Hydrogen tank model is a simple mathematical model which calculates the hydrogen consumption and by which to compute the amount of hydrogen in the tank $\left(\right.$ tank $\left._{\text {level }}\right)$, but, does not include the movement of the hydrogen laterally. The hydrogen consumption can be calculated from the hydrogen consumption rate $\left(f_{H_{2}}\right)$ and mass flow rate $\left(\dot{m}_{H_{2}}\right)$.

The $f_{H_{2}}$ can be estimated based on applied current $I_{F C}$, the number of cells $\left(N_{\text {cell }}\right)$, and Faraday's constant.

$$
f_{H_{2}}=\frac{I_{F C} \cdot N_{\text {cell }}}{2 F}
$$

The $f_{H_{2}}$ is then related to mass flow rate as:

$$
\dot{m}_{H_{2}}=M \cdot f_{H_{2}}
$$

where, $M$, the molecular weight of hydrogen is $2 \mathrm{~g} / \mathrm{mol}$. Then, by using the initial hydrogen content in the tank $M_{\text {tank_init }}$ used to determine the tank level or remaining hydrogen in the tank as below.

$$
\operatorname{tank}_{\text {level }}=\frac{M_{\text {tank_init }}}{\dot{m}_{H 2}}
$$

Note that a normalised tank $k_{\text {level }}$ value (0-1) is used to indicate level of hydrogen in the tank.

\subsubsection{Battery}

Because of a simple mathematical formulation and ease of implementations, a circuit based electrical model of a Li-ion battery is created. The electrical behaviour of the battery cell is modelled using an equivalent circuitbased model [18] as shown in Figure 6.

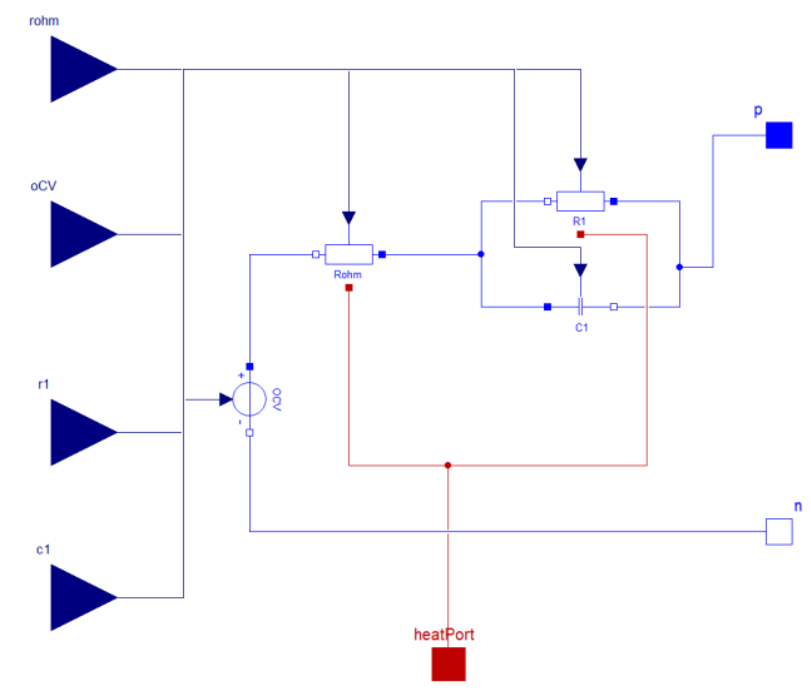

Figure 6. Structure of the electrical circuit model of a $\mathrm{Li}$ ion battery cell.

In Figure 6, the electrical model comprises OCV to represent the open circuit potential $\left(V_{o c v}\right)$, a parallel resistor-capacitor $\left(\mathrm{R}_{1} \mathrm{C}_{1}\right)$ network to model the dynamics part and a series resistor $\left(R_{0}\right)$ to represent instantaneous voltage drop of the battery cell. A set of differential and algebraic equations describe the overall electrical behaviour of the cell is provided below. 


$$
\begin{gathered}
V_{\text {Batt }_{\text {cell }}}=V_{\text {ocv }}-I_{\text {Batt }_{\text {cell }}} R_{0}-U_{d} \\
\frac{d}{d t} U_{d}+\frac{U_{d}}{R_{d} C_{d}}=\frac{I_{\text {Batt }} \text { cell }}{C_{d}} \\
\operatorname{SOC}=\operatorname{SOC}\left(t_{0}\right)-\frac{100}{Q_{\text {rated }}} \int_{t_{0}}^{t_{f}}(I) \cdot d t
\end{gathered}
$$

The equation (14) shows the state-of-charge (SOC) of the battery cell calculated using the ratio of applied current integrated over time to the rated capacity of the battery, $Q_{\text {rated }}$.

Similar to the FC model presented in Section 2.3.2, the individual battery cell model described above is scaled using a specific number of cell in series $\left(\mathrm{N}_{\mathrm{s}}\right)$ and in parallel $\left(\mathrm{N}_{\mathrm{p}}\right)$ to represent battery pack characteristics shown in Figure 7.

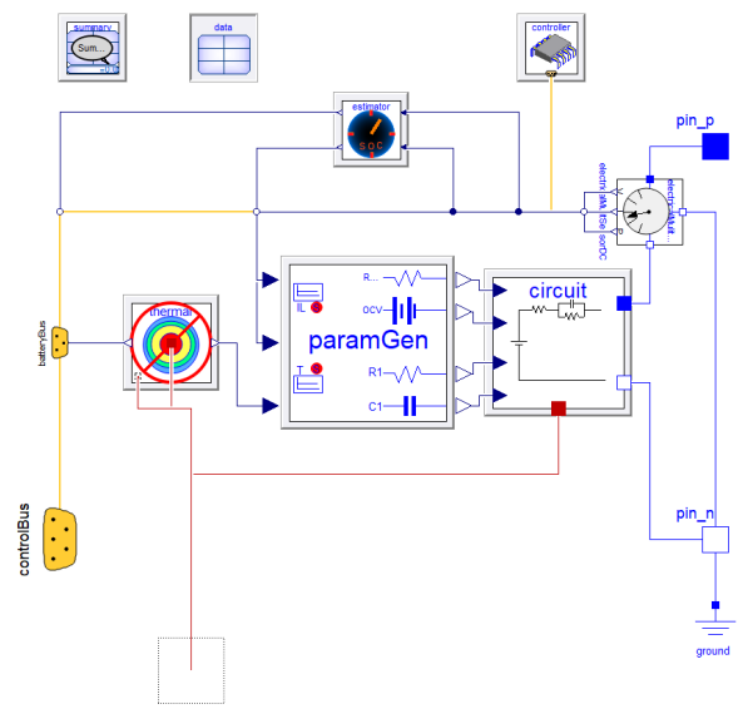

Figure 7. Structure of thermally coupled electrical model of Li-ion battery pack.

Battery energy $\left(E_{\text {batt }}\right)$ consumption is calculated as

$$
E_{\text {batt }}=\int_{t_{\text {init }}}^{t_{\text {op }}} P_{\text {batt }} d t
$$

whereas, $t$ is the time of operation.

An optional 1-D thermal model integrated with electrical model is also available, but not used in this introductory paper. The parameter used in this paper are given in Table 2.

Table 2. Battery model parameter.

\begin{tabular}{|l|l|}
\hline General \\
\hline Manufacture & LiFeBATT \\
\hline Model & $\mathrm{X}-2 \mathrm{E} 40166$ \\
\hline Chemistry & LiFePO4 \\
\hline Total number of cells & 88 \\
\hline Battery cell & \multicolumn{2}{|l|}{} \\
\hline Capacity & $15 \mathrm{Ah}$ \\
\hline Nominal cell voltage & $3.3 \mathrm{~V}$ \\
\hline Inner resistance & $3 \mathrm{~m} \Omega$ \\
\hline Weight & $470 \mathrm{~g}$ \\
\hline
\end{tabular}

\begin{tabular}{|l|l|}
\hline Battery pack \\
\hline Pack configuration & $4 \mathrm{~N}_{\mathrm{p}}, 22 \mathrm{~N}_{\mathrm{s}}$ \\
\hline Main drive voltage & $72 \mathrm{~V}$ \\
\hline Energy & $4.3 \mathrm{kWh}$ \\
\hline Capacity & $59.7 \mathrm{Ah}(\sim=60 \mathrm{Ah})$ \\
\hline Inner resistance & $18 \mathrm{~m} \Omega$ \\
\hline Weight & $45.12 \mathrm{~kg}$ \\
\hline
\end{tabular}

\subsubsection{Auxiliary Load Unit}

The ALU is simple model to simulate electrical accessories in the $\mathrm{H} 2 \mathrm{EV}$, such as $\mathrm{A} / \mathrm{C}$ (heater \& demister), electronics etc. For the sake of simplicity, within this model, the electrical power consumption is assumed to be constant provides a constant power demand if active and no power demand if deactivated.

In this paper, this ALU is used carry out some investigation on how the additional load impacts the vehicle range under different operating conditions.

\subsubsection{Electric Drivetrain}

The electric drive (ED) model consists of motor and power electronics. The implemented ED is a map-based model which absorbs or delivers power based on the input torque signal received. Acceleration demands will send a positive torque request whereas braking demands will send a negative torque request.

\subsubsection{Driveline (Transmission)}

H2EV uses a belt drive transmission to power the front wheels; however, in this paper, given we are not interested in more detailed driveability effects, a fixed ratio reduction gear is implemented.

\subsubsection{Brakes (includes Regenerative) \& Wheels}

The braking subsystem design is used in this paper uses a force input from the brakes control bus dictating the interaction of the braking regeneration systems and the physical braking system through the addition of the HybridDemand block.

For the sake of simplicity, an ideal rolling wheel is used.

\subsubsection{Body with Mass \& Aerodynamics}

An essential part of vehicle modelling is mass and aerodynamics of the vehicle. The vehicle is subject to the propulsive force due to powertrain torque and the aerodynamic and rolling resistance force to movement of the vehicle.

This model defines basic aerodynamic forces applied at the centre of pressure; using drag coefficients. The forces are calculated in the chassis frame, so the forces are parallel to the axes of the frame and are affected by the attitude of the vehicle.

A mathematical description of this part of model is provided in the following Section 3.1. 


\subsubsection{Control Bus}

In Dymola, a control bus creates a communication link between the physical and control parts of the model.

\section{Mathematical Description}

This section of the paper is intended to provide the major equations used to build the entire vehicle model in Dymola. We are interested only the longitudinal vehicle dynamics. As we shown in the rest of this paper, one can combine the following equations together with the previously provided equations to do various systemlevel analysis of a vehicle virtually.

\subsection{Chassis model}

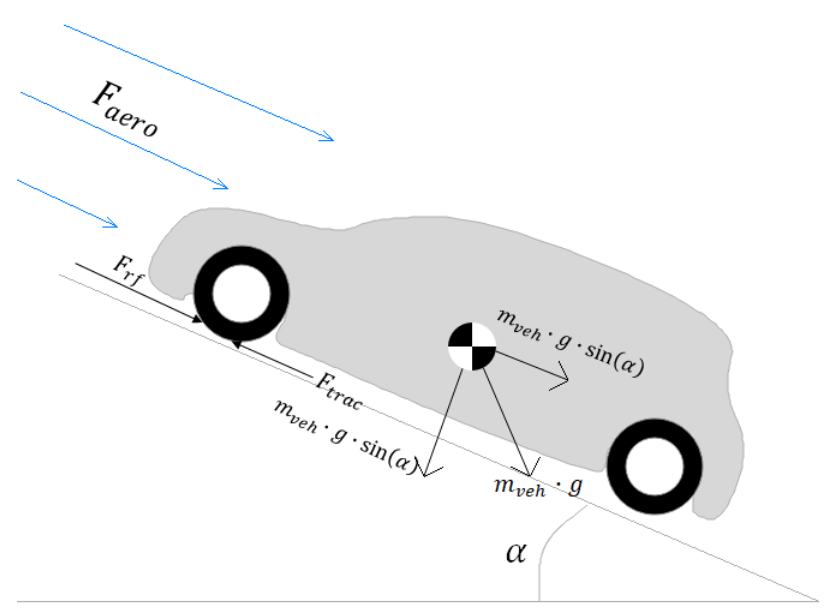

Figure 8. Forces acting on a vehicle.

The longitudinal vehicle dynamics of vehicle can be written as $[19,20]$

$$
\begin{gathered}
F_{\text {trac }}(t)=F_{\text {aero }}(t)+F_{\text {roll }}(t)+F_{\text {grad }}(t) \\
+F_{\text {net }}(t)
\end{gathered}
$$

where, $F_{\text {trac }}$ and $F_{\text {roll }}$ are traction force and rolling friction of the front tyres (due to a front-wheel drive topology of H2EVs), $F_{\text {aero }}$ is the aerodynamic friction and $F_{\text {grad }}$ is the grade climbing resistance.

The aerodynamic drag force can be calculated as

$$
F_{\text {aero }}=\frac{c_{d} \cdot A_{f} \cdot \rho_{\text {air }} \cdot v_{\text {veh }}{ }^{2}}{2}
$$

where, $c_{d}=0.482$ is the drag coefficient, $A_{f}=2.72$ $\mathrm{m} 2$ is the frontal area, $\rho_{\text {air }}$ is air density at current location (about $1.2 \mathrm{~kg} / \mathrm{m} 3$ at sea level and normal temperature) and $v_{v e h}$ speed of the vehicle.

The rolling resistance can be defined as

$$
F_{\text {roll }}=c_{r} \cdot m_{\text {veh }} \cdot g \cdot \cos (\alpha)
$$

whereas, $c_{r}=0.017$ is the rolling resistance coefficient, $m_{v e h}$ mass of the vehicle, $g=9.81 \mathrm{~m} / \mathrm{s} 2$, the acceleration due to gravity and $\alpha$ is the inclination angle.

The force required to overcome grade climbing resistance is given as

$$
F_{\text {grad }}=m_{v e h} \cdot g \cdot \sin (\alpha)
$$

The net force is calculated as

$$
F_{n e t}=m_{v e h} \cdot a_{v e h}
$$

where, $a_{v e h}$ as the acceleration of the vehicle.

Finally, tractive effort delivered by powertrain is given by

$$
F_{\text {trac }}=\frac{G}{r} T_{m o t}
$$

where, $G$, gear ratio of the system connecting the motor to the axle, $r$, tyre radius and $T_{m o t}$ is the torque of the motor.

In order to overcome all the resistances outlined above, a sufficient power must be generated by main and/or secondary power units. The aggregation of these powers can be collectively called as electrical power of the powertrain.

The electric power to the motor represented as

$$
P_{e l}=P_{b a t t}+P_{a u x}-P_{F C}+P_{r e g}
$$

where, $P_{\text {batt }}$ the battery power, $P_{a u x}$ represents the parasitic (auxiliary) load of the vehicle, $P_{F C}$ is the fuel cell power, and $P_{\text {reg }}$ is the power due to regeneration.

In eq. (22), if motor power is positive, then, the battery power is calculated as:

$$
P_{\text {batt }}=\frac{P_{a u x}+P_{m o t}}{\eta_{t}}
$$

where $P_{\text {aux }}$ is the constant power drain from other vehicle systems, such as air conditioners, other subsystems etc.

On the other hand, in eq. (22), if the motor power is negative, then, the regenerative power is used as:

$$
P_{\text {reg }}=P_{\text {aux }}+P_{\text {mot }} \times \eta_{t}
$$

\section{Energy Efficiency \& Range Estimation}

\subsubsection{Energy Efficiency}

The efficiency of drivetrain is calculated as [9]

$$
\eta_{t}=\eta_{\text {ele }} \cdot \eta_{\text {trans }}=\frac{P_{\text {wheels }}}{\left[P_{\text {ele }}\right]}
$$

whereas, $\eta_{\text {ele }}$, the motor and its controller's electrical efficiency, $\eta_{\text {trans }}$ represents the efficiency of the transmission, $P_{\text {wheels }}$, mechanical power at wheels.

\subsubsection{Range Estimation}

As stated in the introduction section, the $\mathrm{H} 2 \mathrm{EV}$ is a series hybrid vehicle most suited for urban trips. Two modes of operation are possible: (1) EV and (2) FCEV modes. Under the normal FCEV operating condition, the FC stack ( $3 \mathrm{~kW}$ Horizon stack) allows a constant load to the battery pack up to the battery voltage rises above a specific pre-set value of $87 \mathrm{~V}$ [9]. By this time the FC stack will power down to $300 \mathrm{~W}$ (as an ideal mode). The FC stack kicks in again if a sufficient power demand is required otherwise it is automatically turned off after half an hour. Therefore, the following equations are used 
for estimating the range of the vehicle using both $\mathrm{EV}$ and FCEV modes.

\subsubsection{EV Mode}

The driving range of pure battery electric mode, $R_{E V}$ can be estimated from the simulation of the vehicle model. This can be expressed are as following;

$$
R_{E V}=v_{x} \cdot t_{E V_{-} o p}
$$

\subsubsection{FCEV Mode}

The range estimation of FCEV mode is given as,

$$
R_{\text {FCEV }}=v_{x} \cdot t_{\text {FECV_op }}
$$

where, $t_{F E C V \_o p}$ is calculated based on hydrogen consumption rate.

However, the total range of the vehicle can be estimated by combining above two ranges.

\section{Results and Discussion}

As aforementioned, in this paper, we use three types of drive cycles (1) UDC, (2) CDC and (3) JC03 to initially validate the model and then to predict the $\mathrm{H} 2 \mathrm{EV}$ performance under different operating conditions. Although this paper is intended to present both EV and FCEV modes operation, but, because of the page limit, the FCEV part is removed from the rest of the discussion section. However, this part will be provided in the future paper.

\subsection{Model Validation}

The first step in the analysis part is to validate the developed model using both standard and real-world drive cycles.

\subsubsection{Standard Driving conditions (Rolling Road Test)}

This section of the paper focuses on validation of the developed H2EV model using standard (UDC or ECE15) drive cycles.

In Figure 9, the estimated range on EV mode is 7.951 $\mathrm{km}$, whereas on the real test is $7.952 \mathrm{~km}$ [9]. battery SOC is depleted much quicker than CDC drive cycle. Both, the target and actual velocities matches well, therefore, its hard to distinguish the difference.

\section{ECE-15 on EV mode}
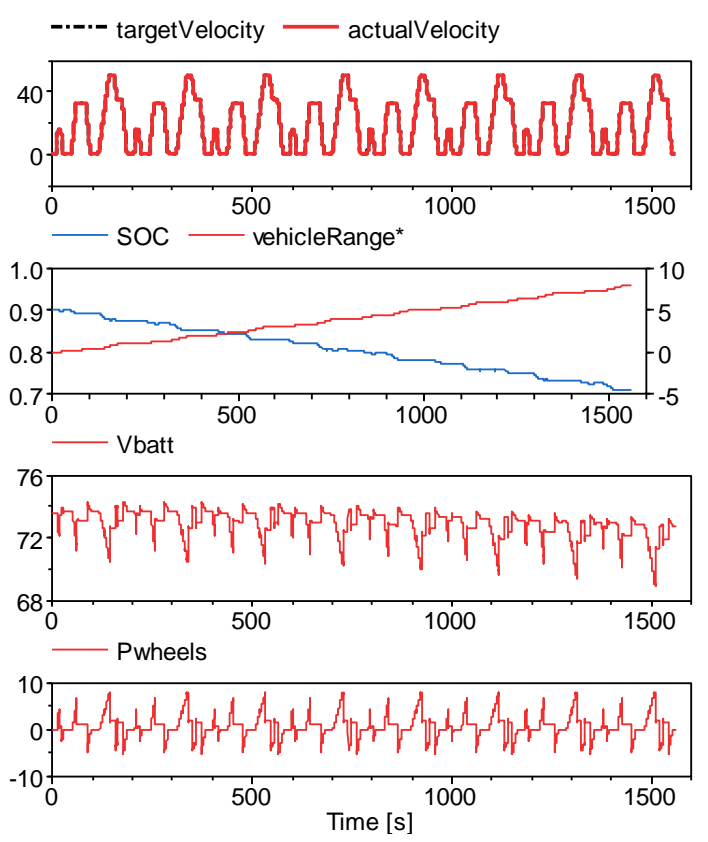

Figure 9. H2EV simulation result using 8 UDC drive cycles.

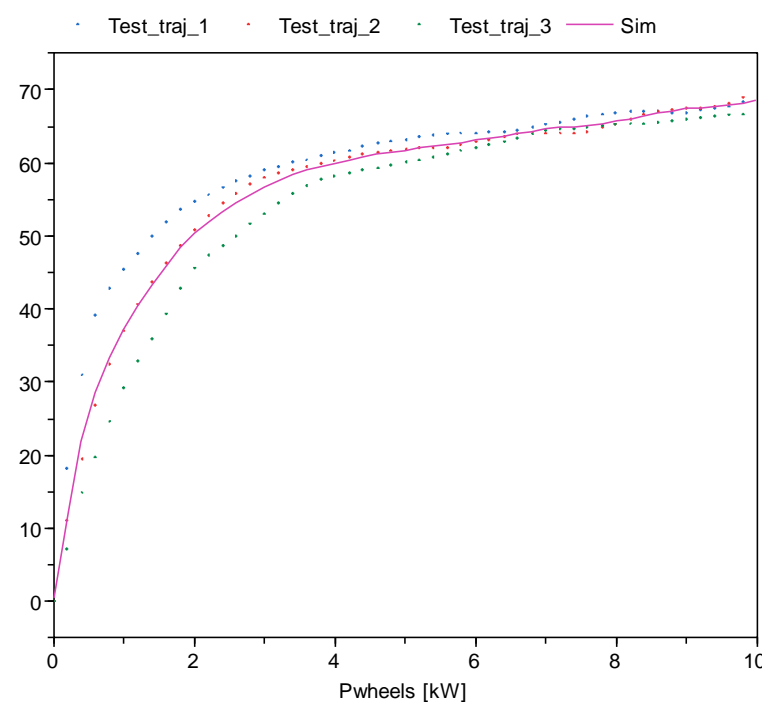

Figure 10. H2EV powertrain efficiency versus power at wheels.

Comparing to the result provided in [9], the predicted value from the model is obtained within the range plotted in Figure 10.

Figure

\subsubsection{CDC on EV mode (with and without FC weight)}



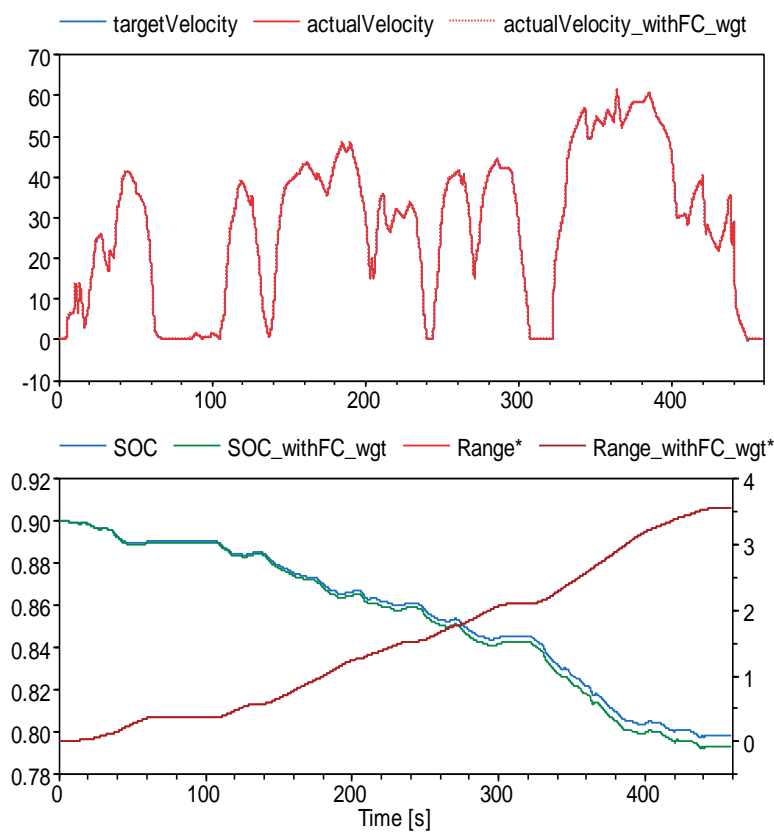

Figure 11. Typical CDC based on [9] with $3.58 \mathrm{~km}$ lap.

Figure 11 shows simulation result obtained from the H2EV model present in this paper using Dymola. The target velocity (test data) matches well with actual velocity (simulation result). In Figure 11 also depicts the EV range of the vehicle which is $3.54 \mathrm{~km}$ from simulation shows good agreement with the $3.58 \mathrm{~km}$ provided in [9].
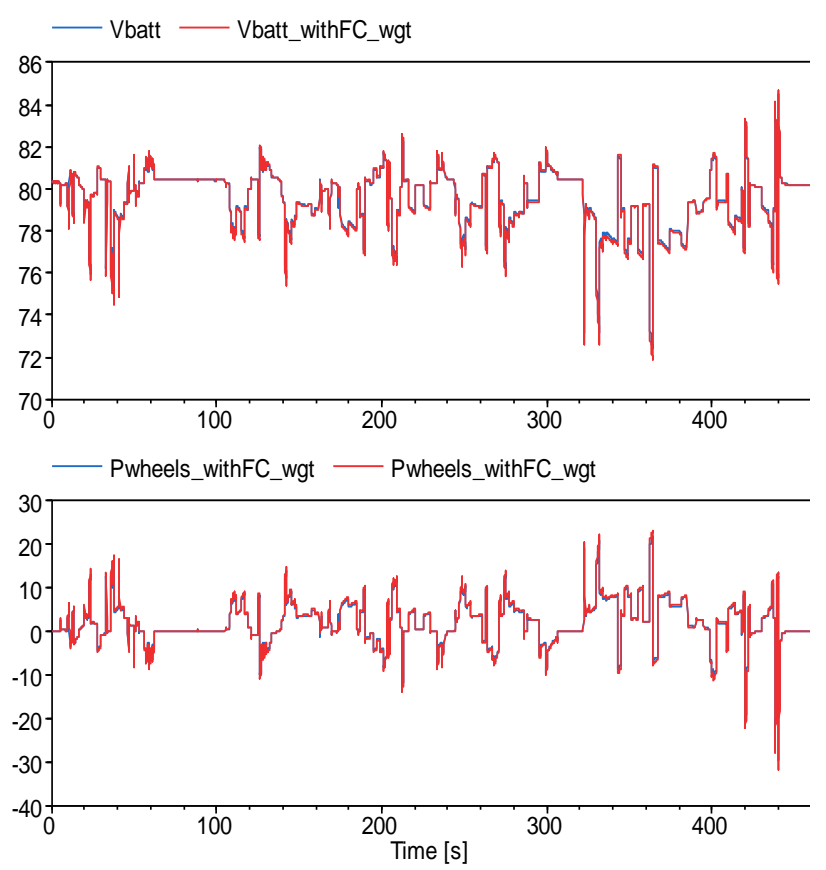

Figure 12. Battery voltage and power at wheel using CDC.

\subsection{Model Prediction}

In this section we simulate the model using JC08 drive cycle to investigate vehicle powertrain performance and energy efficiency in Japanese road driving conditions.

\subsubsection{Standard (Japanese) Drive Cycle}

\section{JC08 on EV mode}

In Figure 13, the both the simulation result and test data have good agreements using JC08 drive cycle. However, battery SOC is depleted much quicker than CDC drive cycle.
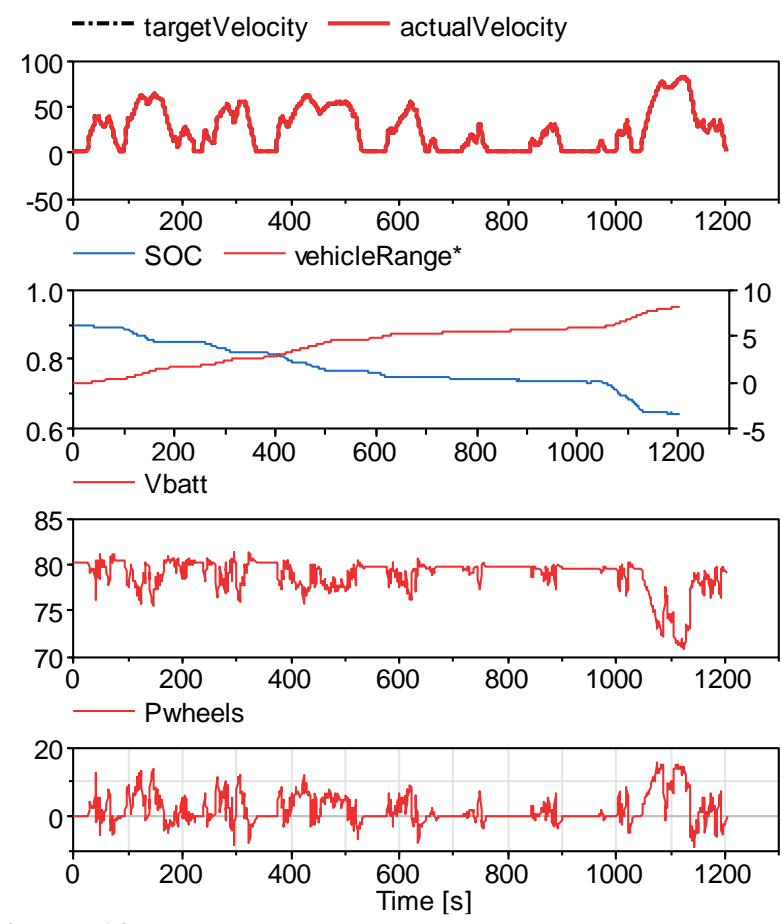

Figure 13. Standard Japanese JC08 drive cycle 
Table 3. Summary of the fuel economy estimation of Microcab H2EV and Commercial [9,22, 23].

\begin{tabular}{|c|c|c|c|c|c|c|}
\hline Vehicle & \multicolumn{5}{|c|}{$H 2 E V$} & Commercial \\
\hline Drive cycle & $\begin{array}{c}\text { UDC } \\
\text { (EV mode) }\end{array}$ & $\begin{array}{l}\text { Repeated UDC } \\
\text { (FCEV mode) }\end{array}$ & $\begin{array}{c}\text { CDC } \\
\text { (EV mode) }\end{array}$ & $\begin{array}{c}\text { JC08 } \\
\text { (EV mode) }\end{array}$ & $\begin{array}{c}\text { Repeated JC08 } \\
\text { (FCEV mode) }\end{array}$ & $\begin{array}{c}\text { Repeated JC08 } \\
\text { (FCEV mode) }\end{array}$ \\
\hline $\begin{array}{l}\text { Battery Power } \\
(\mathrm{Wh} / \mathrm{km})\end{array}$ & 102 & $\begin{array}{c}128.3 \\
(\mathrm{FR}=33.5 \mathrm{~km})\end{array}$ & 126 & & & - \\
\hline $\begin{array}{l}\text { FC Power } \\
(\mathrm{Wh} / \mathrm{km})\end{array}$ & - & 274.9 & - & & & \\
\hline $\mathrm{g} \mathrm{H} 2 / \mathrm{km}$ & - & $\begin{array}{c}6.82 \\
(\mathrm{FR}=265 \mathrm{~km})\end{array}$ & - & & & $\begin{array}{c}6.57 \\
(\mathrm{FR}=700 \mathrm{~km})\end{array}$ \\
\hline
\end{tabular}

\subsection{WTW Analysis}

\subsubsection{Effects of Auxiliary Loads (UK and Japan) [9,21].}

For determining the effect of climatic load on driving range of the vehicle, a repeated drive cycle test using both CDC and JC08 is conducted. Then, auxiliary loads based on Table 3 is used to compare the result obtained with and without additional loads using a ALU model is described in Section 2.3.5.

Table 4. WTW calculation parameters based on [9,21].

\begin{tabular}{|l|l|l|}
\hline Load $[\mathrm{W}]$ & UK & Japan \\
\hline Electronics & $400(\mathrm{max})$ & $400(\mathrm{max})$ \\
\hline Fuel cell operation & 300 & 300 \\
\hline $\begin{array}{l}\text { Cabin Heater \& } \\
\text { demister or A/C }\end{array}$ & 2400 & 2400 \\
\hline
\end{tabular}

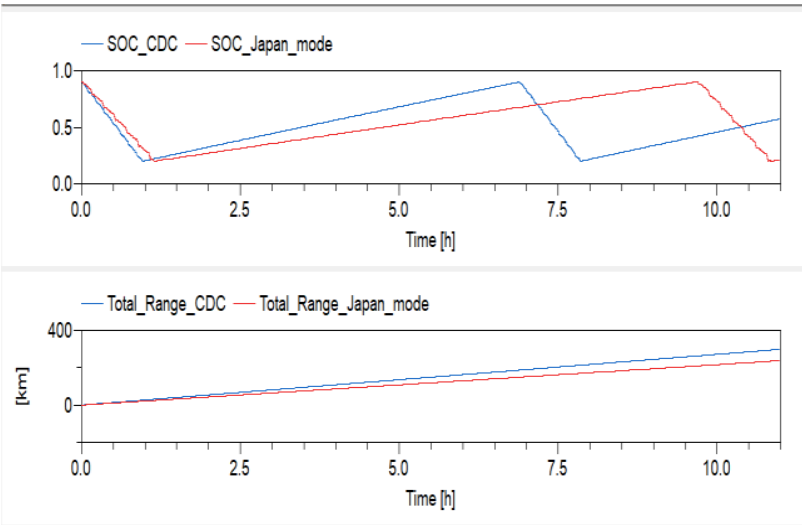

Figure 14. Repeated drive cycle simulation using CDC and JC08 drive cycles.

It is clear from Figure 14 that using FCEV mode, CDC got total range of about $300 \mathrm{~km}$, whereas the Japanese $\mathrm{JC} 08$ is $282 \mathrm{~km}$. This is mainly because of require more energy from the battery pack to complete its drive cycle.

\subsubsection{Well-to-Wheel (WTW)}

Carbon footprint $\left(\mathrm{C}_{\mathrm{f}}\right)$ of the H2EV for both EV and FCEV modes can be calculated based on following equations [9];

\subsubsection{EV Mode}

$$
\mathrm{Cf}=\frac{P_{\text {battEV }} \cdot C_{\text {grid }}}{\eta_{\text {grid }} \cdot \eta_{\text {charger }}}
$$

whereas, $P_{\text {batteV }}$ is the energy consumed by battery in EV mode alone, $C_{\text {grid }}$, grid carbon intensity of the UK or Japan, $\eta_{\text {grid }}$, efficiencies for the grid and $\eta_{\text {charger }}$, efficiencies for the plug-in charger.

\subsubsection{FCEV Mode}

$$
\mathrm{Cf}=\frac{f_{H 2} \cdot C_{H 2}}{\eta_{\text {comp }} \cdot \eta_{\text {trans }}}
$$

whereas, $f_{H 2}$ is the hydrogen consumption rate in FCEV mode, $C_{H 2}$, carbon intensity of the hydrogen production in the UK or Japan, $\eta_{\text {comp }}$, efficiency related to compression pressure of the hydrogen gas and $\eta_{\text {trans }}$, efficiency related to transportation of hydrogen.

Table 5. WTW calculation parameters based on [9,21,22].

\begin{tabular}{|l|l|l|}
\hline & UK (EU) & Japan \\
\hline Grid efficiency [\%] & 86 & 96 \\
\hline $\begin{array}{l}\text { Grid carbon intensity } \\
\text { [gCO2/kWh] }\end{array}$ & 507 & 554 \\
\hline Charger efficiency [\%] & 90 & 90 \\
\hline $\begin{array}{l}\text { Hydrogen production } \\
\text { carbon intensity } \\
\text { [gCO2/kg H2] }\end{array}$ & $\begin{array}{l}\text { [NG: 11888] } \\
\text { [Electrolysis: } \\
970]\end{array}$ & \\
\hline $\begin{array}{l}\text { Efficiency related to } \\
\text { compression pressure of } \\
\text { H2 [\%] }\end{array}$ & $\begin{array}{l}\text { [700 bar: 78] } \\
\text { [350 bar: 87] }\end{array}$ & \\
\hline
\end{tabular}




\begin{tabular}{|l|l|l|}
\hline $\begin{array}{l}\text { Efficiency related to } \\
\text { transportation of } \mathrm{H} 2[\%]\end{array}$ & 88 & \\
\hline
\end{tabular}

Table 5 shows the parameter used in the calculation of WTW in both UK and Japan.

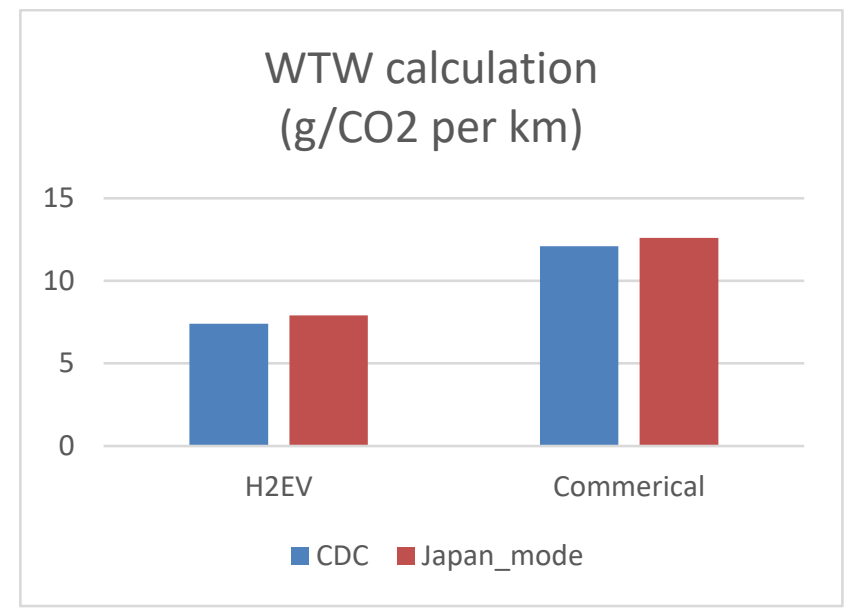

Figure 15. Carbon footprint $\left(\mathrm{C}_{\mathrm{f}}\right)$ based in the UK and Japanese using $\mathrm{H} 2 \mathrm{EV}$ and a commercial vehicle.

Figure 15 shows that by adapting $\mathrm{H} 2 \mathrm{EV}$ or similar vehicle during Japan Olympics 2020 can reduce carbon footprint $\left(\mathrm{C}_{\mathrm{f}}\right)$ and increase the fuel economy. A detailed analysis based on this calculation will be included in the final paper.

\section{Conclusion}

In this research paper an acausal system-level model of a fuel cell plug-in series hybrid electric vehicle (H2EV) is presented. With the help of this system-level model, performance, energy efficiency and carbon foot print of $\mathrm{H} 2 \mathrm{EV}$ are analysed based on different realistic and standard drive cycle tests. Climatic condition of both the UK and Japan has considered while investigating the vehicle range due to additional climatic load. By comparing the results obtained from WTW analysis of $\mathrm{H} 2 \mathrm{EV}$ and a commercial FCHEV show a promising result.

\section{References}

[1] Cazzola, P., Gorner, M., Munuera, L., Schuitmaker, R. and Maroney, E., 2017. Global EV Outlook 2017. International Energy Agency, France.

[2] Steenberghen, T., \& Lopez, E. (2008). Overcoming barriers to the implementation of alternative fuels for road transport in Europe. Journal of Cleaner Production, 16(5), 577-590.

[3] Hayter D., LONDON: a capital for hydrogen and fuel cell technologies, April 2016, HYDROGEN LONDON.

[4] Ju, W. Overview of Fuel Cell Vehicle Development in China, October 16, 2017, Society of Automotive Engineers of China International Hydrogen Fuel Cell Association (IHFCA).

[5] Industry Opportunities: Japan 2020 Olympics, July 2015, Marine International Trade Center, Global Resources. Local Expertise.

[6] Microcab Hydrogen Fuel Cells, http://www.coventry.ac.uk/research/researchcampus/microcab-hydrogen-fuel-cells/. (Last accessed: 05 Feb. 18)

[7] Staffell, I. (2011). Results from the Microcab fuel cell vehicle demonstration at the University of Birmingham. International Journal of Electric and Hybrid Vehicles, 3(1), 62-82.

[8] Barrett, S. (2011). Microcab launches new hydrogen fuel cell microcar for UK demo. Fuel Cells Bulletin.

[9] Ryan, D., Shang, J., Quillivic, C., \& Porter, B. (2014). Performance and energy efficiency testing of a lightweight FCEV Hybrid Vehicle. Eur Electr Veh Congr (EEVC).

[10] Steinmann, W. D., \& Treffinger, P. (2000). Simulation of fuel cell powered drive trains. In Modelica WorkShop.

[11] Treffinger, P., \& Goedecke, M. (2002). Development of fuel cell powered drive trains with Modelica. In Proceedings of the 2nd Modelica Conference (pp. 125131).

[12] Hellgren, J. (2002, March). Modelling of hybrid electric vehicles in Modelica for virtual prototyping. In Proceedings of the 2nd International Modelica Conference (pp. 247-256).

[13] VeSyMA Library, http://www.claytex.com/products/dymola/modellibraries/vesyma/. (Last accessed: 05 Feb. 18).

[14] Microcab H2EV Vehicle Specification, http://www.microcab.co.uk/the-new-h2ev/ . (last accessed 31 Jan 2018).

[15] Horizon Fuel Cell Technologies, 3000W Fuel Cell Stack User Manual, Updated 18 Aug. 2013.

[16] Spiegel, C. (2011). PEM fuel cell modeling and simulation using MATLAB. Academic press.

[17] Larminie, J., Dicks, A., \& McDonald, M. S. (2003). Fuel cell systems explained (Vol. 2). Chichester, UK: J. Wiley.

[18] Uddin, K., Picarelli, A., Lyness, C., Taylor, N. and Marco, J., 2014. An acausal Li-ion battery pack model for automotive applications.Energies, 7(9), pp.5675-5700.

[19] Guzzela, L., \& Sciarretta, A. (2007). Vehicle propulsion systems.

[20] Larminie, J., \& Lowry, J. (2012). Electric vehicle technology explained. John Wiley \& Sons.

[21] Yuu, N., \& Tsuguhiko, N. (2014). A novel concept of AI-EV (air-conditioner integrated electric vehicle) for the advanced smart community. International Conference on Heat Transfer, Fluid Mechanics and Thermodynamics.

[22] Measures to Suppress CO2, http://www.fepc.or.jp/english/environment/global_warmin g/suppress_co2/ (Last accessed: 05 Feb. 18).

[23] Tokieda, J., Ozawa, T., Yoshida, T., Aida, S, and Oya, L. (2015). The MIRAI Life Cycle Assessment Report for communication. Toyota Motor Corporation. 